\title{
The concept of essential facilities in the efficiency of industrial natural resources
}

\author{
Kurnia ${ }^{1, *}$, Bramantyo Suryodhahono ${ }^{2},{\text { Ismala } \text { Dewi }^{1} \text {, and Putri A Saragi }}^{3}$ \\ ${ }^{1}$ Faculty of Law, Universitas Indonesia, Depok, Indonesia \\ ${ }^{2}$ Institute for Business Competition and Policy Studies Universitas Indonesia, Depok, Indonesia \\ ${ }^{3}$ School of Environmental Science, Universitas Indonesia, Salemba, Indonesia
}

\begin{abstract}
Abstact. The concept of 'essential facilities' is known as a tool to request an access of a vital facility to an undertaking having a dominant position in the market. The concept of 'essential facilities' can also be regarded as a code of ethics in the utilization of vital facilities because it regulates the ethics of utilizing it. According to the concept of 'essential facilities', the utilization of a vital facility must be fair and equitable among all parties and none of the parties can dominate it. This doctrine is of course applicable to maintain fair competition within a market. However, by opening an access to a vital facility in natural resources industry, the essential facility doctrine will also be a supporting factor to achieve green industry concept in natural resouces industry. In this paper, SWOT analysis will be conducted to explore the strengths, weaknesses, opportunities, and threats to essential facilities in the efficiency of industrial natural resources with regard to green industry concept, in order to realize a sustainable industry where there is efficiency, effectiveness, and also able to maintain environmental sustainability.
\end{abstract}

\section{Introduction}

Industrialization has now occurred in almost all parts of the world. Industrialization itself was started by the industrial revolution in the 18th century. Since the industrial revolution to date, the existence of industry has been overwhelming and scattered throughout the world, covering a huge number of sectors. China is one of the fastest growing industrialized countries. Industrialization in China and recent declines have greatly affected world commodity prices [1]. However, the existence of this increasingly large industry also affects the current state of the world environment, one of which is the mining industry. The existence of the mining industry has always been a problem because it has disrupted the ecological environment [2]. The existence of an increasing number of industries, if the production process does not pay attention to the existence of natural resources and environmental conditions, can cause serious problems for the world in the future.

Environmental problems caused by the development of industrial existence today has become the world's attention. The need for awareness for the world industrial sector to change the concept to be more environmentally friendly, both from the process of utilization of natural resources and production. Therefore, UNIDO together with the Philippine

\footnotetext{
* Corresponding author: k-toha@ui.ac.id
} 
government held an International Conference on Green Industry in Manila in September 2009 [3]. UNIDO defines the green industry as an industry that encourages sustainable production and consumption patterns, i.e. energy and resource efficiency, low carbon and low waste, without pollution and safe, and environmentally friendly products [4]. One of the countries in Asia who participated in the declaration of Manila is Indonesia which then issued Law No. 3 of 2014 on the industry with the definition of green industry as an industry in the production process prioritize efforts to efficiency and effectiveness of resource use in a sustainable manner, aligning industrial development with the preservation of environmental functions and benefiting society [5].

The change of industry concept to green industry aims to realize a sustainable industry where there is efficiency and effectiveness in the use of natural resources so that in addition to providing benefits to the industry, the industry is also able to maintain environmental sustainability. In China, the green concept has been implemented before the Manila declaration, which since 2007 the development of the green mining industry and the construction of a green mine has been done to address the environmental problems of mining [2]. The concept of green industry can be realized in the use of equipment or facilities that are environmentally friendly or utilization of natural resources that are effective and efficient (which can be renewed better), so the application of green concepts can provide benefits to the industry as well as to the environment.

The term 'essential facilities' can actually be regarded as a doctrine of an economic principle because it relates to the use of essential facilities to meet the needs of each industry. The doctrine of 'essential facilities' requires that for a healthy and competitive business competition, competitors must have access to existing resources in order to start the competition from the beginning fairly [6]. The resources referred here are resources that can be utilized by anyone, not exception by large companies and industries that do require these resources to produce a product. Sometimes, the doctrine of 'essential facilities' also requires undertakings who monopolize the utilization of a essential facility must provide access to facilities deemed essential for the achievement of an effective and fair business competition. Provision of access to the intended facilities must be under the control of the monopolist [7].

The doctrine for the first time was known around 1970, when the US Supreme Court clearly provided a ruling that the monopoly could not refuse the competitor's access to vital assets to compete [8]. As in the formulation of the meaning of the doctrine Essential Facilities is a doctrine that prohibits the abuse of dominant position to deny access or use of essential facilities possessed or controlled by a business actor who has a dominant position, thus causing the competitor's business abilities to be hampered due to rejection access to these essential facilities [9].

The concept of 'essential facilities' is inseparable from the concept of business competition and production activities of a product by the company or industry, but the implementation of these activities must be sustainable and environmentally friendly. Environmentally friendly meant here is by avoiding the exploitation of existing natural resources and utilizing existing resources efficiently. The concept of environmentally friendly in business competition and production activities also means producing a useful product and service without causing environmental problems when the distribution of the products is made to various cities to the country. If a company or industry manages to achieve its production targets without damaging the environment, then they are considered to have successfully carried out the eco-efficiency activities in their business activities [10].

The facility is deemed vital if the facility is very important for the sustainability of the competition because the competitor cannot compete effectively on the relevant market without any access to the facility [11]. The form of a vital facility may be a transport terminal, infrastructure, other transportation facilities, financial, an intellectual property rights permit, or access to software code [12]. While the meaning of vital facilities in this study is a 
downstream distribution pipeline network that flows up to consumers. Thus, the use of the doctrine essential facilities is expected to be used to request access to monopolistic business actors in related industries. So that business actor must open access and cannot make refusal of cooperation (refusal to deal) [13].

In the law of business competition, monopoly garners the most attention. In fact, the monopoly itself is not a crime if it is obtained in a manner that is not illegal and fair. What is prohibited by business competition law is a monopolization that is the actions of a company that has a monopoly position to use its power in the relevant market. This monopolistic practice is the concentration of economic power by one or more business actors resulting in the control of the production and / or marketing of certain goods or services so as to create unfair business competition and may harm the public interest [14]. In other words, the monopoly position itself by companies is not something that is prohibited, but the potential for abuse or monopolization that these companies can do is against the law.

Various literature states that there are many negative impacts related to the monopolization by the perpetrator or a group of business actors that can harm consumers and other business actors, one of which is the entry barrier, where no other company is able to enter the monopoly market for a similar products, so that in turn small companies that are not able to enter the monopoly market will experience the dearth to develop fairly and eventually will go bankrupt. This is in line with the notion of monopoly in the Collins Economy dictionary that monopoly is: "one type of market structure that has properties, that one company with multiple buyers, a lack of substitution or substitution products and a barrier to entry, which cannot be entered by other business actors ". The entry barrier is something that degrades the desire, scope or pace of potential newcomers to enter the market [15]. Shepherd (1991) defines an entry barrier as a condition that makes it harder for new entrants to enter existing markets, where these obstacles can be any form of legal instrument such as licensing as well as a more general economic constraint or any strategic action of an existing company to inhibiting the desire to enter from newcomers [15]. According to the concept of 'essential facilities', the utilization of a vital facility must be fair and equitable among all parties and none of the parties can dominate it. This doctrine is of course applicable to maintain fair competition within a market, eliminating monopolization and abuses from the dominants. However, by opening an access to a vital facility in natural resources industry, the essential facility doctrine can be a key factor to achieve green industry concept in natural resouces industry as the industry will be more efficient by sharing the facilities among undertakings.

\section{Material and method}

The method used in this study is SWOT analysis method. SWOT analysis (SWOT alternative matrix) is an acronym for strengths, weaknesses, opportunities, and threats, i.e. structured planning methods within a company [16]. SWOT analysis in an industry is needed to know the purpose and facilitate the process to be run, so that industry can run effectively and efficiently. In this study, the SWOT analysis will be conducted to explore the strengths, weaknesses, opportunities, and threats to essential facilities in the efficiency of industrial natural resources. Based on identification using these four parameters (strengths, weaknesses, opportunities, and threats), the SWOT matrix determines which ones will be applied to identify four types of strategies, eg power-opportunity strategies (SO), weaknessopportunities (WO), power-threat strategies (ST) and weakness-threat (WT) [18]. The SWOT matrix is created in tabular form, and added by secondary data as support. 


\section{Results and discussion}

In the case of the concept of 'essential facilities' on the efficiency of the industrial natural resources, there are strengths, weaknesses, opportunities, and threats that will be explained more clearly as follows.

\subsection{Strength}

There is competition between each industry in utilizing a facility that is essential or vital to run the business.

\subsection{Weakness}

Tend to feel 'afraid of not getting shares' considering all parties are entitled to access and utilize essential facilities.

\subsection{Opportunity}

There is dominance on one side in the utilization of essential facilities so that their needs remain fulfilled.

\subsection{Threat}

A decrease in production efficiency utilizing natural resources in industries, both the dominant and the dominated.

The following table presents the SWOT on legal protection cases for women environmental activists.

Table 1. SWOT matrix.

\begin{tabular}{lll}
\hline & \multicolumn{1}{c}{$\begin{array}{c}\text { S (Strength) } \\
\text { Internal strength factors }\end{array}$} & \multicolumn{1}{c}{$\begin{array}{c}\text { W (Weakness) } \\
\text { Internal weakness factors }\end{array}$} \\
\hline $\begin{array}{l}\text { O (Opportunity) } \\
\text { External opportunity } \\
\text { factors }\end{array}$ & $\begin{array}{l}\text { SO strategy: create a strategy } \\
\text { using force to take advantage of } \\
\text { opportunities }\end{array}$ & $\begin{array}{l}\text { WO Strategy: create strategies that } \\
\text { reduce weaknesses by taking } \\
\text { advantage of opportunities }\end{array}$ \\
\hline T (Threat) & $\begin{array}{l}\text { ST Strategy: create a strategy } \\
\text { Exing the power to deal with } \\
\text { External threat factors }\end{array}$ & $\begin{array}{l}\text { WT Strategy: create strategies that } \\
\text { reduce weakness and avoid threats }\end{array}$ \\
& threats
\end{tabular}




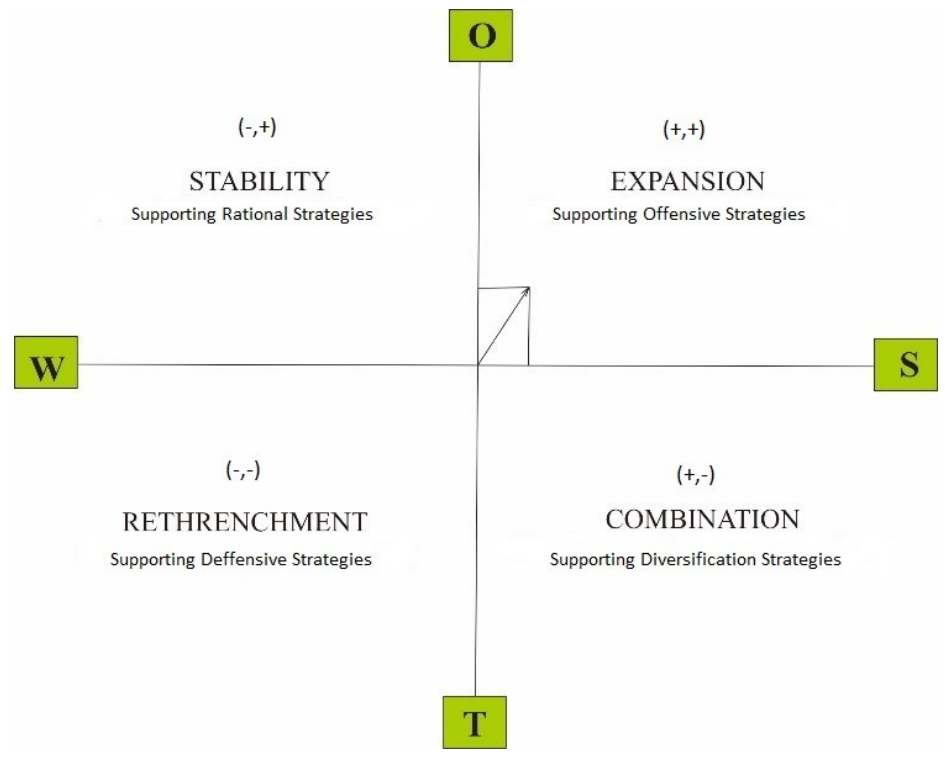

Fig. 1. Cartesian diagram.

In accordance with SWOT analysis results based on each strength, weakness, opportunity, and threat, then for this case SO strategy is used. In this case, it is necessary to create a strategy of using force to exploit opportunities. This strength if maximized can provide opportunities for the effective and sustainable use of natural resources. Essential facilities plays a role in the management and utilization of natural resources. Support vital essential facilities to be "heart" in a system of utilization and management of natural resources. Overall, the problems that have been faced are related to the availability and access of essential facilities.

Natural resources have an important role for human life and the sustainability of a society. Natural resources for various groups of people in Indonesia not only have economic value alone, but also social, cultural, and political meaning. Natural resources play an important role in the formation of civilization in human life. Therefore, every culture and ethnicity has its own distinct and diverse conceptions and views on the mastery and management of natural resources [15]. As from community communities in various places do not have adequate access to natural resources in the vicinity. This is not without reason, but is indeed because of the limitations that are owned especially in terms of downstream of the natural resources.

The public's ability to manage and utilize natural resources encourages outside parties to manage and utilize it. Communities who come from outside the community to manage and utilize the SDA are fully responsible for the sustainability of the utilization process. On the other hand, this SDA will generally be down-streamed through an industrial process to become a valuable product. In the process of industrialization of natural resources as inputs should be used as efficiently as possible. Therefore, the strength of these essential facilities has a very important central role as a force to be used as a reference in exploiting the availability of natural resources. Of course, this opportunity is closely related to the potential for availability and sustainability within the natural ecosystem. It becomes imperative because in the concept of sustainable development optimization of the benefits of natural resources and its integration with natural resources is the determinant of the success of sustainable development [15]. 


\section{Conclusion}

In an effort to realize sustainable development, essential facilities in the efficiency of industrial natural resources become one of the supporting factors. The complexity of the problems of industrialization as a downstream of natural resources is still being felt up to now. Based on the results of this study, it is known that to achieve the goal of sustainable development of the industrial world the concept of essential facilities must be applied. The concept plays a role in creating a strategy of using the inherent strengths therein to exploit law enforcement opportunities in the context of efficient use of natural resources in the industrial world. Thus, the future availability of natural resources and industrial sustainability can be realized.

\section{Acknowledgements}

We, the authors wish to thank the staffs for their time in formatting the manuscript and in supporting the editorial process. Special thanks are also extended, Intan Nurul Aini, and A W Utari for providing data and assisting us in the planning and production of the proceeding. Lastly we would like to thank the Ministry of Research, Technology, and Higher Education of the Republic of Indonesia as this research is funded by the Grant of Penelitian Dasar Unggulan Perguruan Tinggi-KemristekdiktiUniversitas Indonesia 2018 with contract number 271/UN2.R3.1/HKP.05.00/2018.

\section{References}

1. M. Stuermer. Industrialization and the demand for mineral commodities. Journal of International Money and Finance, 76, 16-27 (2017)

2. X. Cheng, Q. Huang, S. Yang, J. Xu, Y. Fan, G. Xu, J. Yang, J. Yuan, W. Qi. Modes and experience of green mine construction in Yunnan, China: case studies. IOP Conference Series: Earth and Environmental Science 95 042080, (2017)

3. UNIDO, United Nations Industrial Development Organization, (2010)

4. Indonesia Ministry of Industry, http://www.kemenperin.go.id/download/6297/ Efisiensi-dan-Efektivitas-dalam-Implementasi-Industri-Hijau, (2012)

5. Undang-undang Republik Indonesia Nomor 3 tahun 2014, http://kemenperin.go.id/download/5181/Undang-Undang-No-3-Tahun-2014Perindustrian.

6. P.A. McNutt, Law, Economics, and Antitrust: Towards A New Perspective (Edward Elgar Publishing Limited, Cheltenham, 2005).

7. T.F. Cotter. The essential facilities doctrine. Antitrust Law and Economics, (2010)

8. G. Vial. Routledge Taylor \& Francis Group (2016)

9. C. Angelo, N. Antonio. Essential facility access in Europe: building a test for antitrust policy. Review of Law and Economics 3, 1 (2007)

10. J.A. Pearce, R.B. Robinson Jr., Manajemen strategis-formulasi, implementasi, dan pengendalian edisi 10 buku 1. Terj. dari Strategic management-formulation, implementation, and control 10th edition (Bachtiar, Y., Christine: Penerjemah). (Salemba Empat, Jakarta, 2008)

11. S.W. Waller. Areeda, epithets, and essential facilities. Wisconsin Law Review, (2008)

12. L. Mays. The Consequences of search bias: how application of the essential facilities doctrine remedies google's unrestricted monopoly on search in the United States and Europe. The George Washington Law Review 83, 2 (2015) 
13. A. Firth, EU Copyright law: the commentary. (Edward Elgar Publishing Ltd., Cheltenham Glos, 2014)

14. A.F. Lubis. A.M. Tri Anggraini, Kurnia Toha, Hukum persaingan usaha; antara teks dan konteks (RDV Creative Media, Jakarta, 2009)

15. I. Widiyanto. Entry barrier antara persaingan potensial dan aktual. Jurnal Bisnis Strategi 5, 2 (2006) 